\title{
Correction to: Trends in Biomathematics: Modeling Cells, Flows, Epidemics, and the Environment
}

\author{
Rubem P. Mondaini
}

\section{Correction to:}

R. P. Mondaini (ed.), Trends in Biomathematics:

Modeling Cells, Flows, Epidemics, and the Environment, https://doi.org/10.1007/978-3-030-46306-9

This book was inadvertently published with errors and the same have been updated later. Chapter title of 21 was revised and also abstract text of Chaps. 17 and 21 was replaced in the online Meta data respectively.

\footnotetext{
The updated online version of these chapters can be found at https://doi.org/10.1007/978-3-030-46306-9_17 https://doi.org/10.1007/978-3-030-46306-9_21 https://doi.org/10.1007/978-3-030-46306-9
} 